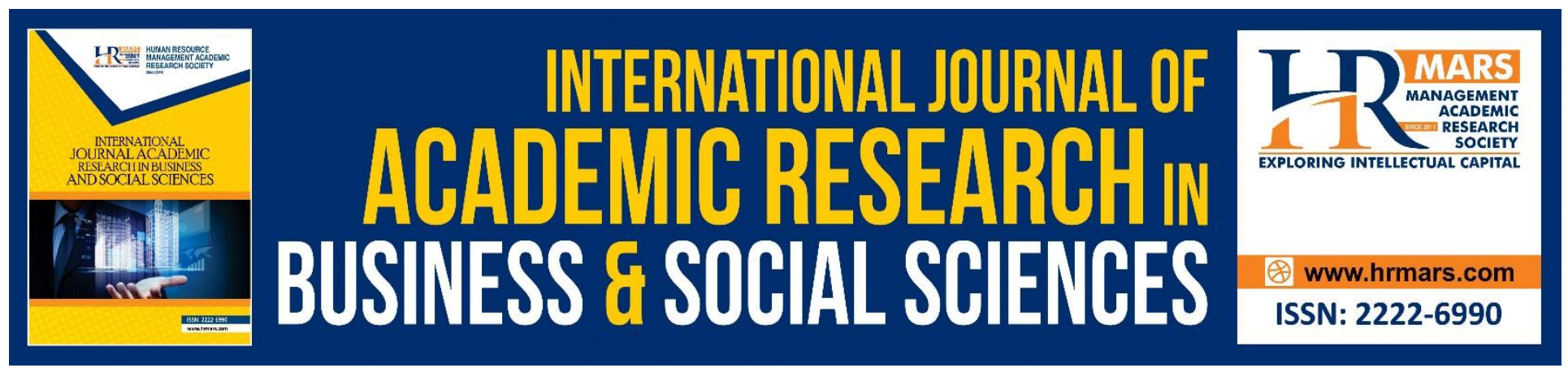

\title{
The Growing Trend of Social Entrepreneurship among Malaysian Undergraduate Students
}

Siti Daleela Mohd Wahid, Wan Mohd Hirwani Wan Hussain, Abu Hanifah Ayob

To Link this Article: http://dx.doi.org/10.6007/IJARBSS/v8-i9/4678

DOI: $\quad 10.6007 /$ IJARBSS/v8-i9/4678

Received: 11 August 2018, Revised: 26 August 2018, Accepted: 29 Sept 2018

Published Online: 14 October 2018

In-Text Citation: (Wahid, Hussain, \& Ayob, 2018)

To Cite this Article: Wahid, S. D. M., Hussain, W. M. H. W., \& Ayob, A. H. (2018). The Growing Trend of Social Entrepreneurship among Malaysian Undergraduate Students. International Journal of Academic Research in Business and Social Sciences, 8(9), 1034-1046.

Copyright: (c) 2018 The Author(s)

Published by Human Resource Management Academic Research Society (www.hrmars.com)

This article is published under the Creative Commons Attribution (CC BY 4.0) license. Anyone may reproduce, distribute, translate and create derivative works of this article (for both commercial and non-commercial purposes), subject to full attribution to the original publication and authors. The full terms of this license may be seen

at: http://creativecommons.org/licences/by/4.0/legalcode

Vol. 8, No. 9, September 2018, Pg. 1034 - 1046

Full Terms \& Conditions of access and use can be found at http://hrmars.com/index.php/pages/detail/publication-ethics 


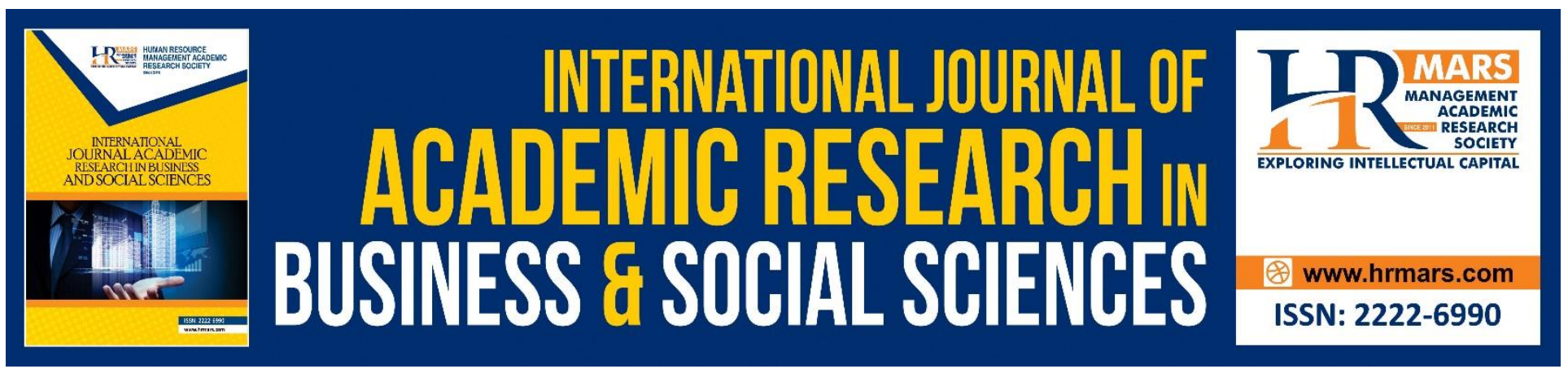

\title{
The Growing Trend of Social Entrepreneurship among Malaysian Undergraduate Students
}

\author{
Siti Daleela Mohd Wahid ${ }^{1,2}$, Wan Mohd Hirwani Wan Hussain², Abu \\ Hanifah Ayob ${ }^{3}$ \\ ${ }^{1}$ Faculty of Business Management Universiti Teknologi MARA Melaka, Malaysia \\ ${ }^{2}$ Graduate Business School, Universiti Kebangsaan Malaysia, Malaysia \\ ${ }^{3}$ Faculty of Economics and Management Universiti Kebangsaan Malaysia, Malaysia
}

\begin{abstract}
Social entrepreneurship is viewed as having the abilities to combat socio-economic problems in which government, businesses, and non-profits may not be able to solve the problems alone. Consequently, the collaboration among these sectors are needed to create social values and development in a nation, specifically among the developing economies. Therefore, it is the best time to investigate the vital factors lead the university's student to form social entrepreneurial intention. This study employed quantitative and cross-sectional approach. The empirical data collected from approximately 1,066 students of Malaysian public universities from multidisciplinary faculties was used. There are eight (8) relationships have been tested. Only five (5) relationships were proven significant and consistent with prior findings. It is hoped that the findings of this study will shed light on the existing literature of social entrepreneurship, specifically the social entrepreneurial intention studies from the emerging economies perspective.
\end{abstract}

Keywords: Social Entrepreneurship, Intention-Behavior Model, Higher Learning Institution.

\section{Introduction}

The social entrepreneurship (SE) study in Malaysia is still at the beginning stage, but, it is seen as the catalyst to solve social problems (Suhaimi et al., 2013). We believe the government has working aggressively to identify the best approach to balance the socio-economic status and need of its rakyat. However, when the government resources and donations are insufficient to address the social problem, the SE is now at a significant point as it enters the mainstream. By seeing the potential in SE field, the government has set up SE unit under the Malaysian Global Innovation and Creativity Center (MaGIC) to spearhead the entrepreneurial community agenda. Through the establishment, the involvement and cooperation among agencies would be stronger in delivering high impact SE projects. 
INTERNATIONAL JOURNAL OF ACADEMIC RESEARCH IN BUSINESS AND SOCIAL SCIENCES Vol. 8, No. 9, Sept. 2018, E-ISSN: 2222-6990 @ 2018 HRMARS

Today, SE research in Malaysia has slowly captured attention among academic scholars, nonprofit organization and policy makers. Malaysia has started developing an environment that is supporting social entrepreneurs with incubators, mentoring, and financial support (Mohd Ali Bahari \& Suhaimi, 2016). In addition, Mohd Ali Bahari \& Suhaimi (2016) stated the emergence of SE is primarily associated to three reasons. Firstly, the growing interest to solve social issues (Mohd Ali Bahari \& Suhaimi, 2016). For example, inequalities (Catford, 1998), poverty and crime (Blackburn \& Ram, 2006). Secondly, SE contributes to the employment development of the country. The idea is that as new businesses are set up, employment opportunities will arise, and unemployment will decrease (Jayeoba, 2015). Thirdly, a growing concern on innovation agenda. An example is PT Foundation which is a community-based, voluntary non-profit organization providing HIV/AIDS education, prevention, sexuality awareness and empowerment program for vulnerable communities in Malaysia. Through their programs, they can serve, educate, and support over 50,000 people annually who are most at risk of HIV in Malaysia.

\section{Motivation of the Study}

As Malaysia is progressively pursuing to become a high-income nation by 2020, an inclusivity agenda has always been the central tenet of Malaysia's government, putting the marginalized group among the top priority. Despite of living in harmony and happy within different ethnicity, the issues of socioeconomic are still happen. Although the international poverty lines are slowly decreasing, there are still 6\% of Malaysian households earn less than RM1, 141 per month. This is roughly 1.9 million Malaysian. This signifies that every twenty Malaysian is deprived of even necessities like living standard, education, and health care and many are still wracked by unemployment and illiteracy (Khazanah Research Institute, 2016).

Entrepreneurship is good for society, leading to innovations, fostering employment and resulting in economic growth (Ernst, 2011). In this sense, SE as a form of entrepreneurial activity can be considered beneficial to society. Additionally, SE targets social needs unmet by government or business. In Malaysia, looking back at a welfare state which has aided since the late 19th century, the government has come to realize that it cannot financially maintain its ample support system. This situation requires an innovative solution to manage and solve social problems.

Social entrepreneurs can prove helpful in eradicating these issues by placing those less fortunate on a pathway towards a meaningful life (Siti Daleela et al., 2018; Tran, 2017). However, the prevalence rate of SE activity in Malaysia is just 2 per cent which is lagged behind of comparable developing countries such as Thailand, Indonesia and Argentina (Radin Siti Aishah et al., 2016). The result in line with Bosma et al. (2016) in Global Entrepreneurship Monitor 2015 (Special Topic Report on Social Entrepreneurship) claiming that the Malaysian citizens who active as social entrepreneurs for 18-64 years bracket is one of the lowest level as compared to other efficiency-driven economies. The fact that SE levels are low is a "problem" for Malaysian society, as the country may be missing out on an innovative way to support its citizens (Wan Mohd Hirwani et al., 2014). According to Wan Mohd Hirwani and colleagues (2014), citizens can be the source of innovative ideas. The citizendriven innovation will introduce divergent thinking which helps to find novel solutions to complex problems. To be a developed nation, innovation will be one of indicators to ensure the country achieve the aim's. 
INTERNATIONAL JOURNAL OF ACADEMIC RESEARCH IN BUSINESS AND SOCIAL SCIENCES

Vol. 8, No. 9, Sept. 2018, E-ISSN: 2222-6990 @ 2018 HRMARS

\section{Literature Review}

Entrepreneurship Intention versus Social Entrepreneurship Intention

As the entrepreneurship intention become mature in the field, SE intention become a new landscape of entrepreneurial realm (Linan \& Fayolle, 2015). SE has promoted the increased numbers of entrepreneurs who motivated to give positive impact for communities (Radin Siti Aishah et al., 2016). Although, the term SE has been used interchangeably with community work and voluntary activities, but, it carried the similar objective in helping the marginalised segment.

Recently, the study on individuals who want to be a social entrepreneur has captured a substantial attention by many researchers (Siti Daleela et al., 2018; Barton et al., 2018; Ip et al., 2017). Linking the theories of entrepreneurial in area of economy, psychology and sociology have driven the preference of these researches to link the entrepreneur's traits construct to prevailing theory and research in the entrepreneurial field (Afsaneh \& Zaidatol Akmaliah, 2014). In other matters, the intention of becoming a social entrepreneur involves individual aspiration to be social entrepreneurs.

Intentions is one of the best beginning of entrepreneurial behavior, particularly when behavior is rare and difficult to observe (Krueger et al., 2000). Mair \& Noboa (2006) are responsible to introduce the first intention-based framework in the context of SE. Social entrepreneurs' intention is a person who has an intention to join social activities are not necessary start a non-profit organization as those who have intention to join social activities must have objective to give huge impact in social (Bosch, 2013). Other than that, SE intentions can be depicted as a man's aim to dispatch a social endeavour or dare to propel social change through advancement (Tiwari et al., 2017).

As a conclusion, intention can predict the behavior of individuals' tendency to be either commercial entrepreneurs or social entrepreneurs. Later, this paper is discussing the factors influencing SE intention.

Factors Influencing Social Entrepreneurship Intention

Having seen that SE in Malaysia is desirable, yet that current levels are very low, leads to one pressing question: how can the levels of SE in Malaysia be increased? Previous studies by (Tiwari et al., 2017; Bosch, 2013; Ernst, 2011) suggested that entrepreneurship can only be increased if the overall quality and quantity of entrepreneurship is fostered. To ensure one's becoming a social entrepreneur, the antecedents influencing their individual intention need to be studied. There are numerous of variables that has been studies, however, the listing here are the most importance variables used by previous academic scholars in the study related to SE intention literature.

I. Personality Traits

Lewellyn \& Wilson (2003) stated that personality traits are enduring, predictable characteristics individual behavior that explain differences in individual actions in similar situations. There is significant predictor to have intention to involved in entrepreneurship field by having a proactive personality (Frank et al., 2007). Most of the studies measuring the personality traits using The Big Five Personality Traits Model by John \& Srivastava (1999) to provide the framework in organizing the variables of personality. As the model significantly used in testify the personality trait relationship, 
INTERNATIONAL JOURNAL OF ACADEMIC RESEARCH IN BUSINESS AND SOCIAL SCIENCES

Vol. 8, No. 9, Sept. 2018, E-ISSN: 2222-6990 @ 2018 HRMARS

this present study also employed The Big Five Personality Traits Model as one of its theoretical foundation.

II. Perceived Social Support

Perceived social support is positively related to SE intentions (Urban \& Teise, 2015). This is because an entrepreneur must totally get support from family especially, their friends and their close one in order to become a social entrepreneur. Social support is important for entrepreneur to maintain their success in challenging environment of nowadays business.

III. Self-Efficacy

Self-efficacy refers to people's belief and confident in their own capabilities to carry out the motivation in themselves, cognitive resources that they have, and courses of action needed in order to exercise control over events in their lives when they choose to act on next decision (Wood \& Bandura, 1989). Self-efficacy influences individual choices in doing business, goals they wanted to accomplish, and emotional reactions that influence their decision, and also refers to the unconditionally belief in one's own ability to realize their main desired goals in business or to perform desired tasks with the right decision and information. Therefore, there is positive relationship between self-efficacy and SE intention (Urban \& Teise, 2015).

\section{Moral Obligation}

Haines et al. (2008) who identify a belief of moral obligation as being positioned between the act of moral obligation and the formation of moral intent. There is a relationship between moral obligation and social entrepreneurship intention (Hockerts, 2017). This is because when an individual has a high motivation to help others so he or she will have high intention to become social entrepreneur. They will look to help the society rather than focusing on profit business.

\section{Attitude Towards Social Entrepreneurship}

According to Ajzen (1991) attitude are referring to what extend person has a favourable or unfavourable evaluation of the behaviour. This also supported by Yang et al (2015) who postulate that if individual's intention to help people in society who are in needed, they can build their positive attitude. In addition, Chipeta (2015) also mention that most important factor that can influence the decision to become an entrepreneur was attitude towards social entrepreneurship itself. It is clearly seen that attitude is an important factor to be considered before entering SE and any other field of study.

VI. Subjective Norm

Subjective norm is referring to how an individual sees the desires of others (Yang et al., 2015). They add that this perception depends on whether 'reference people' approve of the decision to become an entrepreneur, or not. In similar vein, Ernst (2011) has mentioned the perception that the close social surrounding would approve of the subject becoming an entrepreneur. 
INTERNATIONAL JOURNAL OF ACADEMIC RESEARCH IN BUSINESS AND SOCIAL SCIENCES Vol. 8, No. 9, Sept. 2018, E-ISSN: 2222-6990 @ 2018 HRMARS

\section{Perceived Behavior Control}

Perceived behaviour control is the person's conviction about his/her capacity for completing the specific undertaking (Tiwari et al, 2017). In contrast, Bosch (2013) postulate perceived behavioural as the person's view of the straightforwardness or trouble of turning into a business person. Along these lines, a person's conviction will impact the person's behavioural goal and fortify him/her to play out the objective conduct. Furthermore, concerning its definition, perceived behaviour control is the most difficult of the attitude-level in theory of planned behaviour constructs as it refers to how the decision maker has over the behaviour. Ernst (2011) postulate based on theory of planned behavior and all subsequent studies of perceived behaviour control, there is a positive effect of perceive behavioural control on SE intentions.

\section{Empathy}

Empathy is positively related to SE intention (Hockerts, 2017). This is because when an individual understands other feelings and emotional state, he or she will create new business to help those who need help especially. They will concern more on society needs and charity than think about money and profit. This happen because they know the hardness of others to survive. Not all have a best of life, but many are facing difficulties in life and need this kind of entrepreneur to help them.

As a conclusion, we have design the conceptual framework based on the adaptation of three theories namely Theory of Planned Behavior (Ajzen, 1991), SE intention model (Mair \& Noboa, 2006) and Theory of Personality Traits (McCrae \& Costa, 1991). The conceptual framework is as Figure 1

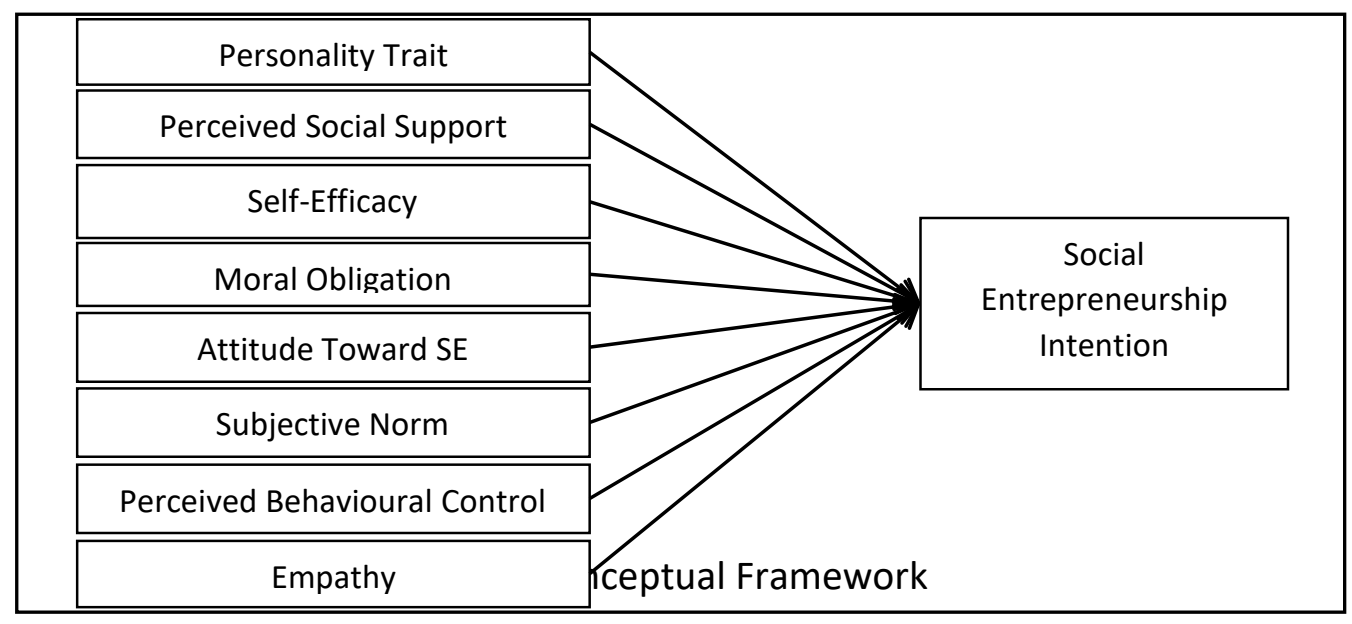

Sources: Adapted from Ajzen (1991), Mc Crae \& Costa (1991), Mair \& Noboa (2006) and Hockerts (2017)

\section{Research Methodology}

This research employed the cross-sectional methodology. The study population consists of undergraduates' student (Bacholer Degree) from multidisciplinary programs and faculties who enrol the subject of Technopreneurship and Principle of Entrepreneurship. The sample came from the 
public universities in Southern Zone of Peninsular Malaysia totalling 1,549 (Semester 2016/2017). The reason behindhand of choosing respondents; they must at least have the basic knowledge of entrepreneurship or social entrepreneurship. Simple random sampling technique was used to collect the sample as the data is available in the university's system. Out of 1,549 questionnaires distributed, 1,066 respondents returned usable questionnaires, giving a response rate of 68.8 percent (see Table 1)

The questionnaires provided the multiple item scale for measuring variables and each item used a 5-point Likert-type response format ranging from 1, "strongly disagree", to 5, "strongly agree". Personality traits were measured using the five dimensions of Big Five Trait Taxonomy with 44-items proposed by John \& Srivastava (1999) which include Extraversion, Agreeableness, Conscientiousness, Neuroticism and Openness. To assess theory of planned behavior factors, the present study adapted and modified from Yang et al. (2015) which represent attitude towards social entrepreneurship were measured using five items, subjective norm - five items and perceived behavioural control - four items. As for SE intention, perceived social support, self-efficacy, moral obligation, empathy; the measurement was adapted from Hockerts (2017) and Medyanik \& Al-Jawni (2017). Nonetheless, before these instruments are used, reliability and validity of instrument were tested where findings exceeded 0.80 (Cronbach's Alpha test). This concluded that the instrument is good and can be used for the purpose of this research. According to Sekaran \& Bougie (2016) when the Cronbach Alpha's closer to 1 , the consistency of reliability is labelled excellent. Therefore, we can conclude that our Cronbach Alpha is acceptable.

The authors have used Statistical Package for Social Science (SPSS) version 20.0 software for data analysis. Next, the demographic information is analysed by descriptive analysis. In this current study, descriptive analysis interpreting the characteristics of the sample including the state campus, faculty and gender. The significant of the test is to measure the (frequency) and percentage of sample profile accordingly (Sekaran \& Bougie, 2016).

In order to testify the relationship among variables, multiple regressions analysis is the most appropriate test to be employed. As proposed by Sekaran \& Bougie (2016), multiple linear regressions analysis is the analysis of association which the effects of two or more independent variables on a single, interval-scaled to dependent variable. There are eight (8) variables have been tested for this study namely: moral obligation, social support, empathy, self-efficacy, perceived behavioural control, personality traits, attitude towards behavior and subjective norms. The result is portrayed in Table 2. Out of 8 , five of them are displaying significant and positive relationship.

\section{Research Hypotheses}

$\mathrm{H} 1$ : Personality traits and SE intention are significantly related

$\mathrm{H} 2$ : There is a positive relationship between perceived social support and SE intention

H3: Self-efficacy is positively related to SE intention

H4: Moral obligation and SE intention are positively significant

H5: Attitude toward SE and SE intention are related.

H6: Subjective norm and SE intention is highly related

H7: Perceived behavioural control has significant relationship with SE intention

H8: Empathy is positively significant to SE intention 
INTERNATIONAL JOURNAL OF ACADEMIC RESEARCH IN BUSINESS AND SOCIAL SCIENCES

Vol. 8, No. 9, Sept. 2018, E-ISSN: 2222-6990 @ 2018 HRMARS

\section{Research Findings and Discussion}

Out of the 1,066 responses, about two thirds of the respondents are female, similar to that of the student population in Malaysian universities. Students from Faculty of Computer and Mathematical Science constituted the largest portion of the respondents (28.4\%), followed by students from Faculty of Business and Management (28.3\%) and Faculty of Administrative Science and Policy Studies (21.5\%). The remaining 21.8 percent of the respondents are from other faculties. The detail demographic information is presented in Table 1.

Table 1 Sample characteristic $(n=1,066)$

\begin{tabular}{lcc}
\hline Variables & Frequency & Percentage \\
\hline Public Universities & 179 & \\
Universiti A & 716 & 16.8 \\
Universiti B & 171 & 67.2 \\
Universiti C & & 16.0 \\
& & \\
Faculty & 92 & 8.60 \\
Faculty of Accountancy & 18 & 1.70 \\
Faculty of Plantation and Agrotechnology & 69 & 6.50 \\
Faculty of Hotel and Tourism Management & 302 & 28.3 \\
Faculty of Business and Management & 303 & 28.4 \\
Faculty of Computer and Mathematical Science & 229 & 21.5 \\
Faculty of Administrative Science and Policy Studies & 53 & 5.00 \\
Faculty of Art and Design & & \\
Gender & & 31.8 \\
Male & 339 & 68.2 \\
Female & 727 & \\
\hline
\end{tabular}

Table 2 Multiple Regressions Result

\begin{tabular}{lcc}
\hline Variables & Beta & Sig. \\
\hline Personality Trait & .070 & .279 \\
Perceived Social Support & .121 & .048 \\
Self-efficacy & .190 & .004 \\
Moral Obligation &. .104 & .086 \\
Attitude Towards Behavior & .124 & .019 \\
Subjective Norm & .146 & .016 \\
Perceived Behavior Control & .375 & .000 \\
Empathy & .035 & .578 \\
\hline
\end{tabular}

Dependent variable $=$ Social Entrepreneurship Intention
$\mathrm{R}=0.623$
$\mathrm{R}^{2}=0.389$
$\mathrm{F}=49.815$
Sig. $=.05$ 
The hypotheses were testing though a single model which measuring direct link among the variables. The $\mathrm{R}^{2}$ of .389 means that a medium amount of variance of SE intention is explained by the independent variables (personality traits, perceived social support, self-efficacy, moral obligation, attitude toward SE, subjective norm, perceived behavioral control and empathy). The measure of $R^{2}$ accounts for variance in dependent variable explained by one or several independents together (Fairchild et al., 2009). Thus, a model that explains an increased amount of the variance of a dependent variable can be considered as preferable.

Most study's findings are significant and positive in nature (Hockerts, 2017; Medyanik \& AlJawni, 2017; Urban and Teise, 2015). However, in this study setting, the result of personality traits $(\mathrm{H} 1)$, moral obligation $(\mathrm{H} 4)$ and empathy $(\mathrm{H} 8)$ are contradict with others' findings. Surprisingly, moral obligation is the only result which reported negative albeit and statistically not significant. The result is presented in Table 2.

As for personality traits $(\mathrm{H} 1)$ the result show insignificant relationship. In similar vein, Politis et al (2016) reported out of five hypotheses developed only the personality trait was totally rejected because it failed to predict social entrepreneurial intentions. This particular finding could be considered interesting since it challenges the theory's effect, at least, in present study. Nga \& Shamuganathan (2010) and Irengun \& Arikboga (2015) who have advocated that the personality traits are better in explaining SE intention. This suggests that the mixed findings from this study regarding personality traits call for further research into the effect personality traits have on social entrepreneurial intentions.

Looking at the result of moral obligation $(\mathrm{H} 4)$, it is obviously contrast with the finding from Hockerts (2017). Hockerts has found the moral obligation is consistent with result from prior research which meaning significant in nature. In this current study it shows insignificant relationship which is in line with the findings from Kedmenec et al. (2015). They mentioned it could be different for an individual probably during the process of running a social entrepreneurial venture. Forster \& Grichnik (2013) find that empathy (H8) has a positive effect on corporate volunteering intentions. However, Ernst (2011) concluded that empathy had a negative effect on a respondent's attitudes toward starting a social enterprise. This mixed finding gives an ample room for future research.

The results provide strong evidence that individuals with perceived social support ( $\mathrm{H} 2)$, selfefficacy $(\mathrm{H} 3)$ tend to have higher social entrepreneurial intentions ( $\mathrm{H} 2)$. The result consistent with findings made by Hockerts (2017) and Kedmenec et al. (2015). There is no denial for the dimension of theory of planned behavior (TPB) variables such as attitude towards SE (H5), subjective norm (H6) and perceived behavior control $(\mathrm{H} 7)$, the results presented here are in line with prior research. For example, Schlaegel \& Koenig (2014) found positive impact of subjective norms on entrepreneurial intentions. Ernst (2011) also found that perceived behavioural had a positive effect on SE intentions of German university students.

\section{Conclusion}

In sum, the students surveyed generally responded positively toward the constructs under investigation. The study found that student exposure in SE activity was likely has great intention to becoming social entrepreneurs. In addition, the determinants like self-efficacy, perceived social support, attitude towards SE, subjective norm and perceived behavior control are significant 
determinants to intention. The practical implications of these results suggest that efforts aimed at increasing social entrepreneurial activity may want to consider the variables studied in this article. Yet, the selection of the variables tested show consistency from prior research findings. Interested parties such as policy makers of higher learning institution and business enterprise wanting to boost the proportion of their alumni involved in SE activity. The findings from this article would suggest policy maker would instil the social entrepreneurship education at university level. Besides, make it as a compulsory activity (minimal credit). For example, UKM-Graduate Business School (GSB) had started this SE activity for their MBA program to ensure their graduate are more valuable, marketable and employable as compared to others university's graduate. Furthermore, due to SE activity, MBA in UKM-GSB manage to introduce nine successful Non-Government Organization (NGO) during their study period collaborate with established social practitioners. This is a good platform for higher learning institutions to be different in their own style.

\section{Acknowledgement}

The authors would like to gratefully acknowledge the time, assistance, and thoughtfulness of all authors who responded to our requests for assistance. We also thank anonymous reviewers for the insights regarding an earlier draft of this paper.

\section{Corresponding Author}

Siti Daleela Mohd Wahid

Universiti Teknologi MARA, Melaka

78000 Alor Gajah Melaka

Malaysia

Email: sitid365@melaka.uitm.edu.my

\section{References}

Ajzen, I. (1991). The Theory of Planned Behavior. Organizational Behavior and Human Decision Processes. 50(2): 179-211.

Afsaneh, B. \& Zaidatol Akmaliah, L.P. (2014). Factors Influencing Students' Entrepreneurial Intentions: The Critical Roles of Personal Attraction and Perceived Control Over Behavior. Proceedings of the 2nd International Conference on Innovation and Entrepreneurship the Institute for Knowledge and Innovation Southeast Asia (IKI-SEA). Bangkok University Thailand 6-7 February 2014

Barton, M., Schaefer, R., \& Canavati, S. (2018). To Be or Not to Be a Social Entrepreneur: Motivational Drivers amongst American Business Students. Entrepreneurial Business and Economics Review, 6 (1): 6-35

Blackburn, R., \& Ram, M. (2006). Fix or Fixation? The Contributions and Limitations of Entrepreneurship and Small Firms to Combating Social Exclusion. Entrepreneurship \& Regional Development. 18(1): 73-89.

Bosch, D.A. (2013). A Comparison of Commercial and Social Entrepreneurial Intent: The Impact of Personal Values. PhD Dissertation. Regent University, London.

Bosma, N., Schøtt, T., Terjesen, S., \& Kew, P. 2016. Global Entrepreneurship Monitor 2015-2016: Special Topic Report on Social Entrepreneurship. 
INTERNATIONAL JOURNAL OF ACADEMIC RESEARCH IN BUSINESS AND SOCIAL SCIENCES

Vol. 8, No. 9, Sept. 2018, E-ISSN: 2222-6990 @ 2018 HRMARS

Catford, J. (1998). Social Entrepreneurs Are Vital for Health Promotion - But They Need Supportive Environments Too. Health Promotion International. 13(2): 95-97

Chipeta, M.E. (2015). Social Entrepreneurship Intentions among University Students in Gauteng. Unpublished Master Dissertation. North West University, Africa.

Economic Planning Unit. (2015). Eleventh Malaysia Plan 2016-2020. Retrieved from http://rmk11.epu.gov.my/book/eng/Eleventh-Malaysia-Plan/RMKe-11Book.pdf

Ernst, K. (2011). Heart Over Mind- An Empirical Analysis of Social Entrepreneurial Intention Formation on the Basis of the Theory of Planned Behaviour. PhD Dissertation. University of Wuppertal, Berlin.

Fairchild, A.J., Mackinnon, D.P., Taborga, M.P., \& Taylor, A.B. (2009). R² Effect-Size Measures for Mediation Analysis. Behavior Research Methods. 41(2): 486-498.

Frank, H., Lueger, M., \& Korunka, C. (2007). The Significance of Personality in Business Start-Up Intentions, Start-Up Realization and Business Success. Entrepreneurship \& Regional Development 19 (3): 227-251

Forster, F., \& Grichnik, D. (2013). Social Entrepreneurial Intention Formation of Corporate Volunteers. Journal of Social Entrepreneurship 4 (2): 153-81

Global Entrepreneurship Monitor Report, 2015

Haines, R, Street, M.D., \& Haines, D. (2008). The Influence of Perceived Importance of an Ethical Issue on Moral Judgment, Moral Obligation, and Moral Intent. Journal of Business Ethics. 2008 (81): 387-399

Hockerts, K. (2017). Determinants of Social Entrepreneurial Intentions. Entrepreneurship Theory and Practices.

Ip, C. Y., Wu, S.C., Liu, H.C., \& Liang, C. (2017). Social Entrepreneurial Intentions of Students from Hong Kong. Journal of Entrepreneurship, 27(1): 47-64

Irengun, O. \& Arikboga, S. (2015). The Effect of Personality Traits on Social Entrepreneurship Intentions: A Field Research. World Conference on Technology, Innovation and Entrepreneurship. Procedia - Social and Behavioral Sciences 195 (2015): 1186 - 1195.

Jayeoba, F.I. (2015) Entrepreneurial Intention and Entrepreneurial Abilities.IFE PsychologIA: An International Journal 23(1): 219-229.

John, O. P., \& Srivastava, S. (1999). The Big-Five trait taxonomy: History, measurement, and theoretical perspectives. In L. A. Pervin \& O. P. John (Eds.), Handbook of Personality: Theory and Research (102-138). New York: Guilford Press.

Kedmenec, I., Rebernik, M., Perip, J. (2015). The Impact of Individual Characteristics on Intentions to Pursue Social Entrepreneurship. Ekonomski Pregled. 66 (2): 119-137

Khazanah Research Institute

Krueger, N.F., Reilly, M.D., \& Carsrud, A.L. (2000). Competing Models of Entrepreneurial Intentions. Journal of Business Venturing. 15(5-6): 411-432

Lewellyn, D. J., \& Wilson, K. M. (2003). The Controversial Role of Personality Traits in Entrepreneurial Psychology. Education+ Training. 45(6): 341-345.

Linan, F., \& Fayolle, A. (2015). A Systematic Literature Review on Entrepreneurial Intentions: Citation, Thematic Analyses, and Research Agenda. New York: Springer Science Business Media. 
INTERNATIONAL JOURNAL OF ACADEMIC RESEARCH IN BUSINESS AND SOCIAL SCIENCES

Vol. 8, No. 9, Sept. 2018, E-ISSN: 2222-6990 @ 2018 HRMARS

Mair, J. \& Noboa, E. (2006). Social Entrepreneurship: How Intentions to Create a Social Venture Get Formed. In J. Mair, J. Robinson, \& K. Hockerts (Eds.), Social Entrepreneurship (121-135). New York: Palgrave MacMillan.

Malaysian Global Innovation and Creativity Centre (MAGIC) (2014/2015)

Malaysian National Development Strategy (My NDS)

McCrae, R. R., \& Costa, P. T., Jr. (1991). The NEO Personality Inventory: Using the Five-Factor Model in Counseling. Journal of Counseling and Development. 69: 367-372.

Medyanik, O. \& Al-Jawni, F. (2017). An Investigation of Students' Social Entrepreneurial Intentions in Syria: An Empirical Test. Springer Proceedings in Business and Economics.

Mohd Ali Bahari, A.K. \& Suhaimi, M.S. (2016). Social Entrepreneurship, Social Entrepreneur and Social Enterprise: A Review of Concepts, Definitions and Development in Malaysia. Journal of Emerging Economies and Islamic Research, 4(2)

National Blue Ocean Strategy (n.d). Retrieved from http://nbos.gov.my/ebook

Nga, J. K. H., \& Shamuganathan, G. (2010). The Influence of Personality Traits and Demographic Factors on Social Entrepreneurship Start up Intentions. Journal of Business Ethics. 95 (2): 259-282

Nicholls, A. (2010). The Legitimacy of Social Entrepreneurship: Reflexive Isomorphism in a PreParadigmatic Field. Entrepreneurship Theory and Practice. 34(4): 611-633

Peng, Z., Lu, G. \& Kang, H. (2012). Entrepreneurial Intentions and Its Influencing Factors: A Survey of The University Students in Xi'An China. Creative Education. 3(8): 95-100

Politis, K, Ketikidis, P, Diamantidi, A.D \& Lazuras, L. (2016). An Investigation of Social Entrepreneurial Intentions Formation Among South-East European Postgraduate Students. Journal of Small Business and Enterprise Development. 23(4): 1120 - 1141

Radin Siti Aishah, R.A.R., Norasmah, O., Zaidatol Akmaliah, L.P., \& Hariyati, A.W. (2016). Entrepreneurial Intention and Social Entrepreneurship Among Students in Malaysian Higher Education. International Journal of Social, Behavioural, Educational, Economic, Business and Industrial Engineering. 10(1): 175-181

Siti Daleela, M.W., Abu Hanifah, A., Wan Mohd Hirwani, W.H. \& Shafinar, I. (2018). Social Entrepreneurship Intention: From Literature Review to Conceptual Framework. Journal of Fundamental Applied Sciences, 10(6S): 1242-1260

Suhaimi, M.S., Abdullah, S., \& Yusof, I. (2013). Practice of Social Entrepreneurship Among the Muslim Entrepreneurs in Malaysia. Middle-East Journal of Scientific Research 14 (11): 1463-1470

Schlaegel, C., \& Koenig, M. (2014). Determinants of Entrepreneurial Intent: A Meta-Analytic Test and Integration of Competing Models. Entrepreneurship Theory and Practice, 38(2): 291-332

Shamsul Hana, A.R. (2012). A Study of Relationship between Family Support, Role Model and Financial Support Towards Entrepreneurial Inclination Among UUM Non-Business Students. Unpublished Master Thesis. Universiti Utara Malaysia

Sekaran, U., \& Bougie, R. (2016) Research Methods for Business A Skill-Building Approach. Sixth edition. John Wiley \& Sons, Inc.

Tiwari, P., Bhat, A.K., \& Tikoria, J., (2017). Predictors of Social Entrepreneurial Intention: An Empirical Study. South Asian Journal of Business Studies. 6(1): 53-79. 
Tran, A.T.P. (2017). Factors Influencing Social Entrepreneurial Intention: A Theoretical Model. Proceedings of 89th ISERD International Conference, Oxford, United Kingdom, 19 - 20 October 2017: 51-57

Urban, B. \& Teise, H. (2015) Antecedents to Social Entrepreneurship Intentions: An Empirical Study in South Africa. Management Dynamics. 24 (2),36-52

Wan Mohd Hirwani, W.H., Mohd Nizam, A.R., Zinatul Ashiqin, Z. \& Noor Inayah, Y. (2014). Mechanism and Government Initiatives Promoting Innovation and Commercialization of University Invention. Pertanika Journal Social Science \& Humanity, 22 (S): 131 - 148

Wood, R. \& Bandura, A. (1989). Social Cognitive Theory of Organizational Management. Academy of Management Review. 14: 361-384

Yang, M. M., Congcong, Z. \& Lingyan, H. (2015). Social Entrepreneurial Intentions China Versus the USA - Is There a Difference. International Journal of Entrepreneurship and Innovation. November 2015: 253-267 